\title{
Inheritance of Abaxial Leaf Pubescence in Beans
}

\author{
Haytham Z. Zaiter ${ }^{1}$ Dermot P. Coyne ${ }^{2}$ James R. Steadman ${ }^{3}$, and James S. Beaver ${ }^{4}$ \\ University of Nebraska, Lincoln, NE 68583-0724 \\ Additional index words. Phaseolus vulgaris, dry bean, snap bean, Uromyces appendiculatus, rust, race-specific \\ resistance, race-nonspecific resistance, morphological resistance, trichome, heritability
}

\begin{abstract}
Genetic variation for abaxial leaf pubescence was detected among dry bean (Phaseolus vulgaris L.) cultivars/ lines. Inheritance of pubescence (long, straight hairs) was studied in the dry bean crosses of pubescent 'Pompadour Checa-50' (Dominican Republic) $\times$ eight glabrous cultivars/lines. Segregation for pubescence vs. glabrousness indicated that pubescence was determined by a single major gene or by duplicate recessive epistatic genes, depending on the cross involved. Trichome density (number trichomes per $\mathbf{m m}^{2}$ ) was a quantitative trait. Thus, pubescence was a discrete trait, but trichome density ranged from low to high.
\end{abstract}

Cultivars of dry beans commonly grown in the United States lack long, straight leaf hairs. However, some dry bean cultivars in the tropics possess long, straight leaf hairs at high density. Genetic variation for trichome type and density occurs in many plant species and has been shown to be associated with insect resistance (Levin, 1973; Ramalho and Ramos, 1979; Rogers, 1979; Webster, 1975). Shaik (1985) first reported negative correlations between leaf pubescence and low intensity of rust, pustules caused by Uromyces appendiculatus (Pers.) Unger var. appendiculatus $[=U$. phaseoli (Pers.) Wint.], in dry beans. Steadman and Shaik (1988) later reported a negative correlation of long, straight hairs on the abaxial leaves of adult plants with rust intensity. The protection offered by the long hairs is greatest when the leaves have not expanded. At such early stages, the leaf hairs are close enough to form a mat over the abaxial surfaces, upon which droplets of water rest without making contact with the leaf epidermis. This phenomenon of water droplets condensing first on the leaf hairs and later forming a water layer was demonstrated by Burrage (1969). Thus, on hairy leaves, the rust germ tubes would be unable to make contact with the leaf epidermis (Alten, 1983).

Rust is among the most destructive of the leaf diseases of dry bean (Kelly, 1982). The bean rust fungus is one of the most variable pathogens known (Vargas, 1980). Breeding of cultivars with race-specific resistance to all the known races of the pathogen and to maintain stability of resistance is difficult. There is a need to explore alternative types of resistance, particularly those that would operate against all races of the fungus (Coyne and Schuster, 1975; Zaumeyer and Harter, 1941; Christ and Groth, 1982).

We found no report on the inheritance of leaf pubescence in $P$. vulgaris, but quantitative inheritance was reported in P. lunatus L. (Lyman and Cardona, 1982). The objectives of this study were to investigate genotypic variation and the inheritance of the abaxial leaf pubescence trait in a wide array of dry bean crosses.

Received for publication 6 Mar. 1989. Published as Paper no. 8855, Journal Series, Nebraska Agricultural Experiment Station. Research was conducted under Title XII Bean/Cowpea CRSP Project-Univ. of Nebraska, Univ. of Puerto Rico, and Dominican Republic under AID Contract no. DAN-1310-G-SS-600800 and also under Project nos. 20-036 and 20-042. The cost of publishing this paper was defrayed in part by the payment of page charges. Under postal regulations, this paper therefore must be hereby marked advertisement solely to indicate this fact.

'Postdoctoral Research Associate, Dept. of Horticulture.

${ }^{2}$ George Holmes Professor, Dept. of Horticulture.

${ }^{3}$ Professor, Dept. of Plant Pathology.

${ }^{4}$ Associate Professor, Dept. of Agronomy and Soils, Univ. of Puerto Rico, Mayaguez, PR 00708.

\section{Materials and Methods}

Plant materials. Greenhouse-grown plants of two pubsecent cultivars [Pompadour Checa-50 (PC50) $\left(\mathrm{P}_{1}\right)$ and Jose Beta 83$21\left(\mathrm{P}_{2}\right)$ ] were crossed in 1987 with eight glabrous cultivars/ lines- 'Chichara' 83-109 $\left(\mathrm{P}_{3}\right)$, A-55 (black bean) $\left(\mathrm{P}_{4}\right)$, 'Agate' (Pinto) $\left(\mathrm{P}_{5}\right)$, EP-1 (Pinto) $\left(\mathrm{P}_{6}\right)$, 'Harris' [Great Northern $(\mathrm{GN})$ ] $\left(\mathrm{P}_{7}\right)$, 'Spinel' $(\mathrm{GN})\left(\mathrm{P}_{8}\right)$, 'EZ Pick' (snap bean) $\left(\mathrm{P}_{9}\right)$, and 78631 (white bean) $\left(\mathrm{P}_{\mathrm{lo}}\right)$. Seeds from single-plant selections (SPS) of each parent were used in crosses. $F_{1}$ plants of each cross (Table 1) were subsequently grown in greenhouse plantings to produce $\mathrm{F}_{2}$ plants. Two pubescent and seven glabrous dry bean cultivars/ lines, $\mathrm{F}_{1}$ of all crosses, and $\mathrm{F}_{2}$ plants of $\mathrm{P}_{1} \times \mathrm{P}_{9}$ and their reciprocals, were grown in the greenhouse in Lincoln, Neb., in Oct. 1987. Pots (1.5-liters) were filled with a potting mixture consisting of equal parts of vermiculite, sand, and soil. Seeds were nicked and sown, and pots of the various populations were arranged in a completely randomized design on a greenhouse bench. The greenhouse was held at 23-26C with a 12-hr day/ night photoperiod. All plants were evaluated for abaxial leaf pubescence. Seeds of the $\mathrm{F}_{2}$ of the remaining crosses and four $\mathrm{F}_{5}$ lines derived from single $\mathrm{F}_{4}$ plants from the cross $\mathrm{P}_{10} \times \mathrm{P}_{1}$ were planted on 1 Dec. 1987 in rows $55 \mathrm{~cm}$ apart and $5 \mathrm{~m}$ long in the field at the Univ. of Puerto Rico, Fortuna Substation, and evaluated for leaf pubescence.

Types of nonglandular hairs. Two types of nonglandular hairs were rated in this study - straight hairs, $\approx 1$ to $2 \mathrm{~mm}$ long, and hooked hairs, $\approx 0.1$ to $0.3 \mathrm{~mm}$ long. Both types of hairs were rated when colloidin leaf impressions were used. Straight hairs only were rated with rapid, unaided eye assessments.

An area $\approx 2 \mathrm{~cm}^{2}$ on each leaf in the interveinal tissue of the abaxial (bottom) surface was selected and smeared with a thin layer of colloidin (Fisher Chemical). Upon drying, the colloidin was peeled off the leaf surfaces. All the details of the epidermis were thus impressed on the colloidin peels. The peel was mounted in distilled water and observed under the microscope at $\times 4$ magnification. The number of impressions of hooked and straight hairs was estimated. Areas with small veins were avoided because of extremely uneven distribution of hooked and long hairs.

Rating scale for leaf pubescence. The nodes and the nodal leaves of 10 bean cultivars/lines were numbered sequentially from the bottom to the top of plants. Thus, the primary leaves at node 1 were both considered as leaf 0 , the first trifoliolate leaf as leaf 1, and the subsequent trifoliolate leaves as leaf 2, 3 , and 4 . Only leaves 0 through 4 on each plant were studied. Trichomes of trifoliolate leaf 4 were studied by means of colloidin leaf impressions (Shaik, 1985) on $\mathrm{F}_{1}$ plants, but were rated by the naked eye for abaxial leaf pubescence of long straight hairs on $\mathrm{F}_{2}$ plants. 
Table 1. Phenotypic classes of parents, $F_{1}$, and $F_{2}$ segregation for pubescence from crosses of two pubescent with eight glabrous bean cultivars and breeding lines.

\begin{tabular}{|c|c|c|c|c|c|}
\hline \multirow[b]{2}{*}{ Parent or cross } & \multicolumn{2}{|c|}{ No. plants observed } & \multirow{2}{*}{$\begin{array}{l}\text { Expected } \\
\text { ratios } \\
\end{array}$} & \multirow[b]{2}{*}{$\chi^{2}$} & \multirow[b]{2}{*}{$P$} \\
\hline & Pubescent $t^{z}$ & Glabrous & & & \\
\hline Pompadour Checa-50 $\left(\mathrm{P}_{1}\right)$ & 14 & 0 & & & \\
\hline Jose Beta 83-21 $\left(\mathrm{P}_{2}\right)$ & 8 & 0 & & & \\
\hline Chichara 83-109 & 0 & 4 & & & \\
\hline$A-55\left(P_{4}\right)$ & 0 & 4 & & & \\
\hline Agate $\left(\mathrm{P}_{s}\right)$ & 0 & 3 & & & \\
\hline $\mathrm{EP}-1\left(\mathrm{P}_{6}\right)$ & 0 & 3 & & & \\
\hline Harris $\left(\mathrm{P}_{7}\right)$ & 0 & 4 & & & \\
\hline Spinel $\left(\mathrm{P}_{8}\right)$ & 0 & 4 & & & \\
\hline 'EZ Pick' $\left(\mathrm{P}_{9}\right)$ & 0 & 4 & & & \\
\hline $\begin{array}{c}78631\left(\mathrm{P}_{10}\right) \\
\mathrm{P}_{9} \times \mathrm{P}_{1}\end{array}$ & 0 & All & & & \\
\hline$F_{1}$ & 16 & 0 & & & \\
\hline $\begin{array}{c}\mathrm{F}_{2} \\
\mathrm{P}_{1} \times \mathrm{P}_{9}\end{array}$ & 33 & 10 & $3: 1$ & 0.07 & $0.80-0.90$ \\
\hline$F_{1}$ & 15 & 0 & & & \\
\hline $\begin{array}{c}\mathrm{F}_{2} \\
\mathrm{P}_{2} \times \mathrm{P}_{3}\end{array}$ & 26 & 11 & $3: 1$ & 0.44 & $0.50-0.70$ \\
\hline $\mathrm{F}_{1}$ & 20 & 0 & & & \\
\hline $\begin{array}{c}F_{2} \\
\mathrm{P}_{3} \times \mathrm{P}_{2}\end{array}$ & 18 & 2 & $3: 1$ & 2.40 & $0.10-0.20$ \\
\hline $\mathrm{F}_{1}$ & 22 & 0 & & & \\
\hline $\begin{array}{c}\mathrm{F}_{2} \\
\mathrm{P}_{1} \times \mathrm{P}_{2}\end{array}$ & 10 & 7 & $3: 1$ & 2.37 & $0.10-0.20$ \\
\hline$F_{1}$ & 36 & 0 & & & \\
\hline $\begin{array}{c}F_{2} \\
P_{1} \times P_{3}\end{array}$ & 107 & 0 & $107: 0$ & & \\
\hline $\mathrm{F}_{1}$ & 42 & 0 & & & . \\
\hline $\begin{array}{c}\mathrm{F}_{2} \\
\mathrm{P}_{1} \times \mathrm{P}_{4}\end{array}$ & 137 & 46 & $3: 1$ & 0.001 & $0.95-1.00$ \\
\hline$F_{1}$ & 12 & 0 & & & \\
\hline $\begin{array}{c}F_{2} \\
P_{5} \times P_{1}\end{array}$ & 58 & 20 & $3: 1$ & 0.02 & 0.90 \\
\hline $\mathrm{F}_{1}$ & 24 & 0 & & & \\
\hline $\begin{array}{c}\mathrm{F}_{2} \\
\mathrm{P}_{1} \times \mathrm{P}_{6}\end{array}$ & 82 & 66 & $9: 7$ & 0.04 & $0.80-0.90$ \\
\hline$F_{1}$ & 33 & 0 & & & \\
\hline $\begin{array}{c}F_{2} \\
P_{6} \times P_{1}\end{array}$ & 210 & 138 & $9: 7$ & 2.37 & $0.10-0.20$ \\
\hline$F_{1}$ & 24 & 0 & & & \\
\hline $\begin{array}{c}F_{2} \\
P_{7} \times P_{1}\end{array}$ & 162 & 129 & $9: 7$ & 0.04 & $0.80-0.90$ \\
\hline$F_{1}$ & 31 & 0 & & & \\
\hline $\begin{array}{c}\mathrm{F}_{2} \\
\mathrm{P}_{8} \times \mathrm{P}_{1}\end{array}$ & 154 & 115 & $9: 7$ & 0.11 & $0.70-0.80$ \\
\hline$F_{1}$ & 12 & 0 & & & \\
\hline $\begin{array}{c}F_{2} \\
P_{5} \times P_{6}\end{array}$ & 45 & 30 & $9: 7$ & 0.41 & $0.50-0.70$ \\
\hline$F_{1}$ & 0 & 16 & & & \\
\hline$F_{2}$ & 0 & 65 & & & \\
\hline$P_{7} \times P_{6}$ & & & & & \\
\hline $\mathrm{F}_{1}$ & 0 & 18 & & & \\
\hline $\begin{array}{c}F_{2} \\
P \times P\end{array}$ & 0 & 116 & & & \\
\hline $\begin{array}{c}P_{8} \times P_{6} \\
F_{1}\end{array}$ & 0 & 18 & & & \\
\hline $\mathrm{F}_{2}$ & 0 & 90 & & & \\
\hline $\mathrm{P}_{10} \times \mathrm{P}_{1}$ & & & & & \\
\hline$F_{5}-87-56$ & 35 & 15 & $3: 1$ & 0.70 & $0.20-0.50$ \\
\hline$F_{5}-87-57$ & 121 & 32 & $3: 1$ & 1.36 & $0.10-0.20$ \\
\hline$F_{5}-87-62$ & 19 & 3 & $3: 1$ & 1.55 & $0.20-0.50$ \\
\hline$F_{5}-87-63$ & 103 & 38 & $3: 1$ & 0.27 & $0.50-0.95$ \\
\hline
\end{tabular}

${ }^{2}$ Leaf pubescence was recorded on the abaxial side of the fourth leaf. Plants rated $1=$ glabrous; $2,3,4$, and $5=$ pubescent. 
Table 2. Segregation for pubescence in $F_{3}$ families of the reciprocal cross PC50 $\left(\mathrm{P}_{1}\right) \times$ snap bean 'EZ Pick' $\left(\mathrm{P}_{\mathrm{q}}\right)$.

\begin{tabular}{lcccc}
\hline \hline & $\begin{array}{c}\text { No. } \\
\text { nonsegregating } \\
\text { for } \\
\text { pubescence }\end{array}$ & $\begin{array}{c}\text { No. } \\
\text { segregating } \\
\text { for } \\
\text { pubescence }\end{array}$ & $\begin{array}{c}\text { Expected } \\
\text { ratio }^{z}\end{array}$ & $P$ \\
Crosses & 9 & 8 & $1: 2$ & $0.05-0.1$ \\
$\mathrm{P}_{1} \times \mathrm{P}_{9}$ & 5 & 11 & $1: 2$ & $0.80-0.90$ \\
$\mathrm{P}_{9} \times \mathrm{P}_{1}$ & 5 & & \\
\hline
\end{tabular}

${ }^{z}$ Heterogeneity test for expected ratio (1:2) families: $\chi_{2}=5.69-$ $2.63=3.06(\mathrm{df}=3), P=0.30-0.50$.

A rating scale of 1 to 5 was used to describe hair density on the abaxial leaf area as follows: $1=$ no hairs; $2=1 \%$ to $10 \%$; $3=11 \%$ to $25 \% ; 4=26 \%$ to $50 \%$; and $5=>50 \%$ of area covered. Pubescence ratings were evaluated on fully expanded leaves to eliminate density fluctuations due to leaf expansion (Pillemer and Tingy, 1976). Plants rated 1 were considered glabrous and those rated 2, 3, 4, and 5 pubescent.

Inheritance of pubescence. The $\mathrm{X}^{2}$ method was used to test the goodness-of-fit to particular ratios of glabrous : pubescent plants when bimodal distributions were observed, and to test expected $\mathrm{F}_{3}$ ratios of nonsegregating pubescent : segregating pubescent progenies.

\section{Results and Discussion}

Leaf hair variation. One of the two pubescent cultivar/line sources, 'Pompadour Checa-50' (PC50 SPS) ( $\left.\mathrm{P}_{1}\right)$, had dense long straight hairs on the abaxial surface of leaves 2 and above. The lower leaves of PC50 had either exclusively hooked or a mixture of hooked and straight hairs and were less pubescent (data not shown). The second pubescent cultivar/line, 'Jose Beta' 83-21 $\left(\mathrm{P}_{2}\right)$, was moderately pubescent with long straight hairs on the abaxial surfaces of leaves 2,3 , and 4 but with less density than $\mathrm{P}_{1}$ (data not shown). The other cultivars/lines used in crosses to $\mathrm{P}_{1}$ and $\mathrm{P}_{2}$ were highly to moderately glabrous and totally lacked long straight hairs on the abaxial leaf surfaces (Table 1).

Inheritance of pubescence. Dominance for leaf pubescence, for both long and short hairs, was expressed in all of the $F_{1}$ (pubescent $\times$ glabrous) families and their reciprocals. The parents showed little variation in pubescence, indicating little influence of environment on the expression of the trait. In contrast, variation in degree of pubescence within $F_{1}$ families indicated that heterozygotes were not as stable in the expression of this trait as the homozygous parents. $F_{1}$ families of glabrous $\times$ glabrous parents $\left(\mathrm{P}_{5}, \mathrm{P}_{7}\right.$, and $\left.\mathrm{P}_{8} \times \mathrm{P}_{6}\right)$ and of highly pubescent $\times$ pubescent parents $\left(\mathrm{P}_{1} \times \mathrm{P}_{2}\right)$ were glabrous and pubescent, respectively (Table 1); the $\mathrm{F}_{2}$ families did not segregate. This test for allelism indicated that the parents possessed similar genes controlling this character (Table 1).

A good fit to a 7 glabrous : 9 pubescent ratio of plants occurred in the $\mathrm{F}_{2}$ generations from crosses of Great Northern or Pinto cultivars with the pubescent parents. However, if the glabrous parent was either 'Chichara' 83-109, 'EZ Pick', A-55, or 78631 , the $F_{2}$ and $F_{5}$ segregation showed a good fit to a 1 glabrous : 3 pubescent ratio of plants. In the former set of crosses, we hypothesized that this trait was controlled by duplicate recessive epistatic genes, with pubescence being expressed when both dominant genes were present in the homozygous $(P b-1 / P b-1 P b-2 / P b-2)$ or heterozygous state. In the latter set of crosses, the variation for pubescence was determined by a single gene, suggesting that these glabrous parents were homozygous-dominant at one of the loci determining this trait. We were unable to indicate which locus possessed the dominant alleles.

The $\mathrm{F}_{3}$ segregation from the cross $\mathrm{P}_{1} \times \mathrm{P}_{9}$ confirmed the hypothesis that a single major dominant gene controlled pubescence in that cross (Table 2). The number of $\mathrm{F}_{3}$ families not segregating for pubescence and segregating for pubescence showed a good fit to a 1:2 ratio, respectively (Table 2 ). No heterogeneity for the $\mathrm{F}_{3} 1: 2$ segregation ratio was detected among crosses of $\mathrm{P}_{9} \times \mathrm{P}_{1}$ and their reciprocals (Table 2).

All of the present Great Northern and Pinto cultivars are glabrous and lack nonspecific resistance to rust, so developing lines of these bean classes with high abaxial leaf pubescence using PC50 as a source of pubescence is warranted. Because of the simple inheritance of leaf pubescence, single plant selection for this trait should be effective in segregating progeny of early generations.

\section{Literature Cited}

Alten, H. von. 1983. The effect of temperature, light and leaf age on the frequency of appressoria formation and infection with Uromyces phaseoli (Pers.) Wint. Phytopathol. Z. 107:327-335.

Burrage, S.W. 1969. Dew and the growth of the uredospore germ tube of Puccinia graminis on wheat leaf. Ann. Applied Biol. 64:495501.

Christ, B.J. and Groth, J.V. 1982. Inheritance of virulence in three isolates of bean rust to three bean cultivars. Phytopathology 72:767770 .

Coyne, D.P. and M.L. Schuster. 1975. Genetic and breeding strategy for resistance to rust [Uromyces phaseoli (Re ben.) Wint.] in beans (Phaseolus vulgaris). Euphytica 24:795-803.

Kelly, J.D. 1982. Varietal and class diversity and accentuation of disease problems in a major production area. Rep. Bean Improv. Coop. and Nat. Dry Bean Res. Conf., 5-7 Jan. 1982. Univ. of Florida, Gainesville. p. 12-14.

Levin, D.A. 1973. The role of trichomes in plant defense. Quart. Rev. Biol. 48:3-15.

Lyman, J.M. and C. Cardona. 1982. Resistance in Lima Beans to a leafhopper, Empoasca kraemeri. J. Econ. Entomol. 75:281-286.

Pillemer, E.A. and W.M. Tingy. 1976. Hooked trichomes: A physical plant barrier to a major agricultural pest. Science 193:482-484.

Ramalho, F.S. and J.R. Ramos. 1979. Distribution of eggs of the leaf hopper Empoasca kraemeri Ross and Moore, on bean plants. Anais da Soc. Entomol. Brazil 8:85-92.

Rogers, D.J. 1979. Host plant resistance to Ophiomyia phaseoli (Tryon) (Diptera:Agromyzidae) in Phaseolus vulgaris. J. Austral. Entomol. Soc. 18:245-250.

Shaik, M. 1985. Race-nonspecific resistance in bean cultivars to races of Uromyces appendiculatus var. appendiculatus and its correlation with leaf epidermal characteristics. Phytopathology 75:478-481.

Steadman, J.R. and Shaik, M. 1988. Leaf pubescence confers apparent race-nonspecific rust resistance in bean (Phaseolus vulgaris). Phytopathology 78:1566. (Abstr.)

Vargas, E. 1980. Rust, p. 17-36. In: H.F. Schwartz and E.G. Galvez (eds.). Bean production problems. Centro lntl. de Agr. Trop. (CIAT), Cali, Colombia.

Webster, J.A. 1975. Association of plant hairs and insect resistanceAn annotated bibliography. USDA Misc. Publ. 1297.

Zaumeyer, W.J. and Harter, L.S. 1941. Inheritance of resistance to six physiologic races of bean rust. J. Agr. Res. 63:599-622. 